\title{
Phytoprotection
}

\section{Herbicide-resistant crops in resistant weed management : An industrial perspective}

\section{Shaner}

Volume 75, numéro 4, 1994

Herbicide Resistance Workshop - Edmonton, Alberta - 9 and 10 december 1993

Atelier sur la résistance aux herbicides - Edmonton (Alberta) - 9 et 10 décembre 1993

URI : https://id.erudit.org/iderudit/706074ar

DOI : https://doi.org/10.7202/706074ar

Aller au sommaire du numéro

Éditeur(s)

Société de protection des plantes du Québec (SPPQ)l

ISSN

0031-9511 (imprimé)

1710-1603 (numérique)

Découvrir la revue

Citer cet article

Shaner, D. (1994). Herbicide-resistant crops in resistant weed management : An industrial perspective. Phytoprotection, 75(4), 79-84.

https://doi.org/10.7202/706074ar
Résumé de l'article

Parmi les premiers produits issus de la biotechnologie à atteindre le marché se trouvent les cultures résistantes aux herbicides. L'industrie envisage le développement de cultivars résistants aux herbicides comme une façon d'accroître la disponibilité d'herbicides éprouvés pour une gamme de cultures plus vaste. Cependant, le développement de cultures résistantes aux herbicides requiert une attention particulière envers certaines questions environnementales, à savoir l'utilisation des herbicides, la sélection de biotypes de mauvaises herbes résistants et la transmission de gènes de résistance entre ces cultures et des espèces sauvages. L'industrie tente activement de répondre à ces préoccupations pendant le processus de développement. Un développement adéquat et une utilisation judicieuse des cultures résistantes aux herbicides, dans le cadre de programmes de lutte intégrée contre les mauvaises herbes, procureront aux producteurs agricoles une flexibilité et une efficacité accrues, ainsi qu'une diminution des coûts associés à la répression des mauvaises herbes, sans augmenter le risque d'obtenir des mauvaises herbes résistantes aux herbicides. De plus, les cultures résistantes aux herbicides devraient constituer des outils précieux dans la gestion des mauvaises herbes résistantes aux herbicides.
Ce document est protégé par la loi sur le droit d'auteur. L'utilisation des services d'Érudit (y compris la reproduction) est assujettie à sa politique d'utilisation que vous pouvez consulter en ligne.

https://apropos.erudit.org/fr/usagers/politique-dutilisation/ 


\title{
Herbicide-resistant crops in resistant weed management: An industrial perspective
}

\author{
Dale Shaner ${ }^{1}$
}

Received 1993-10-28; accepted 1994-07-11

\begin{abstract}
Some of the first products of biotechnology to reach the marketplace have been herbicide-resistant crops. Industry sees the development of herbicideresistant varieties as a way to increase the availability of proven herbicides for a broader range of crops. However, the development of herbicideresistant crops requires special attention to potential environmental questions such as herbicide usage, selection of resistant weed biotypes and spread of resistance from the resistant crop to wild species. Industry is actively addressing these concerns during the process of development. Proper development and use of herbicide-resistant crops in integrated weed management programs will provide farmers with increased flexibility, efficiency, and decreased cost in their weed control practices without increasing the risk of herbicide-resistant weeds. Furthermore, herbicideresistant crops should prove to be valuable tools in managing herbicideresistant weeds.
\end{abstract}

Shaner, D. 1994. Cultures résistantes aux herbicides et gestion des mauvaises herbes résistantes: Perspectives de l'industrie. PHYTOPROTECTION 75 (Suppl.): 79-84.

Parmi les premiers produits issus de la biotechnologie à atteindre le marché se trouvent les cultures résistantes aux herbicides. L'industrie envisage le développement de cultivars résistants aux herbicides comme une façon d'accroître la disponibilité d'herbicides éprouvés pour une gamme de cultures plus vaste. Cependant, le développement de cultures résistantes aux herbicides requiert une attention particulière envers certaines questions environnementales, à savoir l'utilisation des herbicides, la sélection de biotypes de mauvaises herbes résistants et la transmission de gènes de résistance entre ces cultures et des espèces sauvages. L'industrie tente activement de répondre à ces préoccupations pendant le processus de développement. Un développement adéquat et une utilisation judicieuse des cultures résistantes aux herbicides, dans le cadre de programmes de lutte intégrée contre les mauvaises herbes, procureront aux producteurs agricoles une flexibilité et une efficacité accrues, ainsi qu'une diminution des coûts associés à la répression des mauvaises herbes, sans augmenter le risque d'obtenir des mauvaises herbes résistantes aux herbicides. De plus, les cultures résistantes aux herbicides devraient constituer des outils précieux dans la gestion des mauvaises herbes résistantes aux herbicides.

1. American Cyanamid Company, Princeton, New Jersey, U.S.A. 08543-0400 
Nomenclature of chemical names cited in the text:

Bromoxynil: 3,5-dibromo-4-hydroxybenzonitrile; chlorsulfuron: 2-chloro-N-II(4-methoxy-6methyl-1,3,5-triazine-2-yl)amino]carbonyl]benzenesulfonamide; glufosinate: 2-amino4(hydroxymethylphosphinyl)butanoic acid; glyphosate: $N$-(phosphonomethyl) glycine; imazaquin: 2-[4,5-dihydro-4-methyl-4-(1-methylethyl)-5-oxo-1H-imidazol-2-yl]-3-quinolinecarboxylic acid; sethoxydim: 2-[1-(ethoxyimino)butyl]-5-[2-(ethylthio)propyl]-3-hydroxy-2-cyclohexen-1-one).

\section{INTRODUCTION}

One of the major advances in agriculture was the discovery of selective herbicides that kill weeds while not injuring the crop. By definition these crops are "herbicide-resistant crops", although the mechanisms of resistance existed within the crops before introduction of the herbicide. However, herbicide-resistant crops have come to be defined as crop varieties that have been changed through biotechnological or conventional breeding techniques so that the new varieties can be treated with a herbicide that would kill unaltered varieties.

Some herbicide-resistant crops are already available to farmers. The first such crop to be developed was triazineresistant canola (Brassica napus L.) in Canada in the 1980s (Beversdorf et al. 1988). The availability of this variety provided farmers a way to control cruciferous weeds in canola. In 1992, imidazolinone-resistant maize (Zea mays L.) varieties were introduced in the United States (Press release, American Cyanamid). In the next few years, new crop varieties that are resistant to glyphosate, glufosinate, sulfonylureas, sethoxydim, and bromoxynil will become available (Table 1) (Bright 1991).

The development of herbicide-resistant crops has raised the concern that they will increase problems with herbicide-resistant weeds either by overuse of the same herbicide or by transfer of the resistant trait into wild species (Duke et al. 1991). This is a legitimate concern that has to be addressed during the development and introduction of any new resistant crop varieties. However, this new technology can help in the management of resistant weeds rather than increase the problem by providing farmers with increased choices in their integrated weed management programs.

The objective of this review is to explore the issues raised by the use of herbicide-resistant crops in resistant weed management, and to explain how industry is addressing these areas of concern to insure that they do not become problems.

\section{HERBICIDE-RESISTANT CROPS}

One of the first questions asked of industry is why herbicide-resistant crops should be developed. There are many reasons for the development of these new varieties, but the primary reason is the difficulty in finding new selective herbicides that meet all of the present toxicological and environmental standards. Traditionally, companies find new herbicides through random screening of novel chemicals. In the 1950s, about 1 in 2000 screened chemicals resulted in commercial products. In the 1970s, over 7000 compounds had to be screened in order to find a commercial product; in the 1980 s, this rate dropped to 1 in 20000 (Mazur and Falco 1989). Today, companies have to test even more compounds before one is found that has commercial potential. In addition, the cost of developing a new herbicide is in excess of $\$ 80$ millions (Powell and Jutsum 1993).

One of the most difficult herbicide properties to discover in a new compound is crop selectivity, particularly for controlling weeds that are closely related to the crop, such as cruciferous weeds in canola. An alternative approach to synthesizing new analogs that are selective on a particular crop is to genetically modify the crop to resist the herbicide. In this way, farmers can 
use a highly effective herbicide in more diverse ways than its inherent properties allow.

Table 1. Herbicide-resistant crops that are under development

\begin{tabular}{ll}
\hline Crop & Herbicide $^{\text {a }}$ \\
\hline Canola & Glyphosate \\
& Imidazolinones \\
& Triazines \\
& Glufosinate \\
& Sulfonylureas \\
& Glyphosate \\
Soybean & Sulfonylureas \\
& Glufosinate \\
& Glyphosate \\
Sugarbeet & Glufosinate \\
& Sulfonylureas \\
& Imidazolinones \\
& Imidazolinones \\
Maize & Sethoxydim \\
& Glufosinate \\
& Bromoxynil \\
Cotton & Glyphosate \\
& Sulfonylureas \\
& 2,4-D \\
& Imidazolinones \\
&
\end{tabular}

a Data taken from Duke et al. 1991

b Newhouse et al. 1992

\section{POTENTIAL PROBLEMS}

\section{Increased herbicide use}

The availability of herbicide-resistant crops should not result in increased herbicide use in those crops. Most of the areas where a farmer will use a herbicide-resistant crop already receives herbicides as part of the weed control program. For example, over $95 \%$ of the soybean (Glycine max L.) and maize grown in the United States receives at least one herbicide application yearly (Ellis 1992). Because of the low use rates of many of the herbicides for which resistant crops are being developed, the actual quantity of herbicide applied per hectare may be less than what is currently being used (Ellis 1992). These low rates, coupled with the low toxicity of these herbicides to invertebrates and vertebrates, should result in even lower environmental impact than the current situation.

Another related concern about the use of herbicide-resistant crops is that the farmer will indiscriminately apply high rates of the herbicide. However, this will not happen because it will not be cost-effective nor will it be allowed by the label for the herbicide on the crop.

\section{Spread of resistance}

One of the fears associated with using herbicide-resistant crop is that the resistant crop will become a weed, or that the trait will move into associated weeds. It is highly unlikely that herbicide-resistant crops will become serious weed problems. Most crops are non-competitive under natural conditions without man's intervention. Herbicide-resistant crops will not be any more competitive than susceptible cultivars and so will not become any more of a serious weed than their susceptible counterparts (Duke et al. 1991).

The spread of resistance traits to associated weeds is also highly unlikely because most of the crops in which resistance is being developed do not have a closely related weedy counterpart. For example, there are no known cases where genes from maize have crossed into any associated weeds since none of the weeds is closely related to maize. There might be a slightly higher chance of crosses between canola and weedy crucifers. Studies have shown that such crosses are extremely rare events, and are not likely to happen under agricultural conditions since the susceptible weeds within the crop are being controlled by the herbicide (Duke et al. 1991). Coupling this low probability of outcrossing between the herbicide-resistant crop and associated weeds with an integrated weed management program will insure that movement of the resistant trait to the weed populations is of low probability and will not be a serious problem. One aspect that will be necessary with the introduction of herbicide-resistant crops is that farmers will have to control volunteers in succeeding crops with 
a herbicide with a different mode of action than the herbicide used in the resistant crop. For instance, imazaquin effectively controls volunteer maize in soybeans. However, if the previous crop had been imazaquin-resistant maize, then this herbicide would be ineffective. Under these circumstances, the farmer would need to use another herbicide, such as an acetyl-CoA carboxylase (ACCase) inhibitor. However, using a herbicide with another mode of action to control a herbicideresistant volunteer crop is not detrimental since it ensures that farmers will include herbicides with different modes of action in their crop rotation.

\section{Increase in development of resistance}

History has shown that the continuous use of any herbicide alone for weed control favors the selection for resistant weed populations. Sulfonylurearesistant populations of Kochia scoparia (L.) Schrad, Lactuca serriola L., Salsola iberica, and Stellaria media L. Cyrill. were selected within 3-5 yr after the introduction of chlorsulfuron into continuous wheat (Triticum aestivum L.) (Holt et al. 1993). In all of these species, the mechanism of resistance was an altered acetolactate synthase (ALS) enzyme that was no longer inhibited by these herbicides (Holt et al. 1993). If herbicide-resistant crops were used in a system where the same herbicide would be used on the same piece of land for multiple years, then herbicide-resistant weed populations would evolve.

The selection of herbicide-resistant weed populations, however, would defeat the utility of resistant crops. Thus, these crops will only be used as part of an integrated weed management program. Such a program will not depend on the herbicide alone for weed control but rather these herbicides will be part of a multi-pronged weed control program. An integrated program will include using tank mixtures of herbicides and rotating with other herbicides with different modes of action, combining mechanical, cultural and biological weed control methods with herbicides, and using the minimal amounts of herbicide to control weeds.

\section{BENEFITS OF HERBICIDE- RESISTANT CROPS}

If properly managed, herbicide-resistant crops will aid in management of resistant weeds rather than increase the problem, by giving farmers more flexibility in weed management. In recent years, populations of Avena fatua L., Lolium multiflorum Lam., Sorghum halepense (L.) Pers. and Setaria viridis (L.) Beauv. have developed resistance to ACCase-inhibiting herbicides (Holt et al. 1993). In all of these cases, these herbicides were the only means used to control grassy weeds. If farmers had used ACCase inhibitors in combination or rotation with herbicides with different modes of action, they could have avoided this situation, or at least delayed it. However, in many cases, farmers could not use other herbicides that could control these weedy grasses in the infested crops because these other herbicides lacked selectivity. With the introduction of herbicide-resistant crops, the farmer will have the option of using herbicides with different modes of action to prevent selection of resistant weed populations. A potential scenario showing how herbicide-resistant crops increase the herbicide options for canola, and so can be used to reduce the selection pressure on the weed population, is shown in Table 2.

\section{RESISTANCE MANAGEMENT}

Taking steps to ensure that the introduction of herbicide-resistant crops helps rather than hinders management of herbicide-resistant weeds begins with the development of these new varieties. Companies introducing these crops are taking these steps. They include educating and training sales persons and growers, developing weed management programs that include herbicides with multiple modes of action, writing labels with warnings on resistance development, and working with university and extension personnel on resistance management recommendations. The agrochemical 
Table 2. Herbicides avaible for controlling grasses and cruciferous weeds in canola and proposed or existing herbicide-resistant canola in Canada

\begin{tabular}{lcc}
\hline Herbicides & Canola & Herbicide-resistant canola \\
\hline Target weed group: grasses & & \\
Dinitroaniline & $\sqrt{ }$ & $\sqrt{ }$ \\
Cyclohexanediones & $\sqrt{ }$ & $\sqrt{ }$ \\
Aryloxyphenoxypropionates & - & $\sqrt{ }$ \\
Imidazolinones & - & $\sqrt{ }$ \\
Glufosinate & - & $\sqrt{ }$ \\
Glyphosate & & $\sqrt{ }$ \\
& $-\sqrt{ }$ \\
Target weed group: crucifers & - & $\sqrt{ }$ \\
Sulfonylureas & - & $\sqrt{ }$ \\
Triazines & - & $\sqrt{ }$ \\
Imidazolinones & - & $\sqrt{ }$ \\
Glyphosate & & $\sqrt{ }$ \\
Glufosinate & & \\
\hline
\end{tabular}

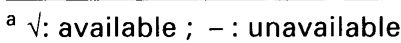

industry also has organized intercompany groups, such as the Herbicide Resistance Action Committee and its working groups, to exchange information on the development and spread of herbicide-resistant weeds and to develop uniform guidelines on managing resistant weeds (Jutsum and Shaner 1992).

Companies are testing and developing herbicide mixtures or sequential programs for use in resistant crops. These programs include herbicides with different modes of action that control those weed species that appear to be at highest risk for developing resistance. In this way the probability of selecting resistant biotypes is greatly reduced because the weed population would have to develop resistance to two modes of action simultaneously. Companies are including warnings on their labels about the potential for selecting for resistance and how to avoid this problem.

Companies are also working closely with university and extension personnel during the development of herbicide-resistant varieties. They supply seeds of resistant varieties to these researchers so they can determine how these new varieties and the associated herbicides perform in their particular area. Companies actively seek input from university and extension personnel on the role of herbicide-resistant crops in the weed control programs in their areas and how they can use these crops in resistance management.

\section{REFERENCES}

Beversdorf, W.D., D.J. Hume, and M.J. Donnelly-Vanderloo. 1988. Agronomic performance of triazine-resistant and susceptible reciprocal spring canola hybrids. Crop Sci. 28: 932-934.

Bright, S.W.J. 1991. Opportunities for introducing herbicide-resistant crops. Pages 365-374 in J.C. Caseley, G.W. Cussans, and R.K. Atkin (eds.), Herbicide resistance in weeds and crops. ButterworthHeinemann, Oxford.

Duke, S.O., A.L. Christy, F.D. Hess, and J.S. Holt. 1991. Herbicide-resistant crops. Comments from CAST 1991-1. 24 pp.

Ellis, J.F. 1992. Herbicide development and marketing of weed control in the United States of America. Proc. $1^{\text {st }}$ Int. Weed Control Congr. 1: 74-82.

Holt, J.S., S.B. Powles, and J.A.M. Holtum. 1993. Mechanisms and agronomic aspects of herbicide resistance. Annu. Rev. Plant Physiol. Mol. Biol. 44: 203-229. 
Jutsum, A.R., and D. Shaner. 1992. Herbicide resistance: the stance of the agrochemical industry. Proc. $1^{\text {st }}$ Int. Weed Control Congr. 2: 244-246.

Mazur, B.J., and S.C. Falco. 1989. The development of herbicide-resistant crops. Annu. Rev. Plant Physiol. Mol. Biol. 40: 441-470.
Newhouse, K.E., W.A. Smith, M.A. Starrett, T.J. Schaefer, and B.J. Singh. 1992. Tolerance to imidazolinone herbicides in wheat. Plant Physiol. 100: 882-886.

Powell, K.A., and A.R. Jutsum. 1993. Technical and commercial aspects of biocontrol products. Pestic. Sci. 37: 315-321. 